\title{
SEX DIFFERENCES IN RISK FACTORS FOR ACUTE STROKE
}

\section{RAZLIKE PO POLU U FAKTORIMA RIZIKA ZA NASTANAK AKUTNOG MOŽDANOG UDARA}

\author{
Sara Milenković', Biljana Georgijevski Brkić2, Miloš Maksimović3', Đorđe Radak, ', Jadranka Maksimović'
}

\section{Summary}

Stroke is one of the leading causes of morbidity and mortality in both developed countries and developing countries.

The aim of this study is to examine whether there are differences in demographic characteristics, life habits (e.g.smoking and consumption of alcohol) and medical anamnesis of men and women diseased by acute stroke.

Using cross - sectional study, the patients that were diagnosed with acute stroke and hospitalized in the period from November $1^{\text {st }}$ to November 30 ${ }^{\text {th }}$ 2014. In Special Hospital for Cerebrovascular Diseases Sveti Sava in Belgrade were taken into account. Discharge lists from these patients were read through and analyzed giving data about general demographic characteristics, life habits (e.g. smoking and alcohol consumption) and medical anamnesis (arterial hypertension, diabetes mellitus, dyslipidemia, cardiac disorders (arrhythmia, the heart failure, coronary artery disease ), atherosclerosis). For statistical analysis we used the $x^{2}$ and $t$ - test.

The total number of hospitalized patients with the diagnosis of acute stroke in the given period was 113 , of which 57 were males (50.4\%) and 56 females (49.6\%). The average age of patients with stroke was significantly higher in women than in men $(t=2.62 ; D F=111 ; p=0.010)$. Men were significantly more likely to consume alcohol than women $\left(x^{2}=7.35 ; p=0.007\right)$, while in the other examined risk factors for acute stroke, there was no statistically significant difference between men and women.

The results point that men and women with acute stroke statistically significantly differ in relation to age and alcohol consumption.

Keywords: acute stroke, sex, health habits, personal history

\section{Sažetak}

Akutni moždani udar je jedan od vodećih uzroka obolevanja i umiranja kako u razvijenim zemljama sveta tako i u zemljama u razvoju.

Cilj ove studije je ispitati da li postoje razlike u demografskim karakteristikama, životnim navikama (pušenje cigareta, konzumiranje alkohola) i ličnoj anamnezi između muškaraca ižena obolelih od akutnog moždanog udara.

Studijom preseka, obuhvaćeni su pacijenti sa dijagnozom akutnog moždanog udara koji su hospitalizovani u period 1-31. novembra 2014. godine u Specijalnoj bolnici za cerebrovaskularna oboljenja Sveti Sava u Beogradu. Detaljnim pregledom otpusnih lista svih pacijenata, prikupljeni su podaci 0 osnovnim demografskim karakteristikama, životnim navikama (pušenje cigareta i konzumiranje alkohola) i ličnoj anamnezi (arterijska hipertenzija, dijabetes, dislipidemija, kardiološki poremećaji (aritmija, srčana dekompezacija, koronarna bolest), ateroskleroza). U statističkoj obradi podataka korišćeni su $x^{2} i t$ - test.

Ukupan broj hospitalizovanih pacijenata sa dijagnozom akutnog moždanog udara u datom periodu bio je 113, od toga 57 muškaraca (50,4\%) i 56 žena (49,6\%). Prosečan uzrast pacijenata sa moždanim udarom bio je značajno vecí kod žena nego kod muškaraca $(t=2,62 ; D F=111 ; p=0,010)$. Muškarci su značajno češće konzumirali alkohol u odnosu na žene $\left(x^{2}=7,35 ; p=0,007\right)$, dok u ostalim ispitivanim faktorima rizika za nastanak akutnog moždanog udara nije bilo statistički značajnih razlika između muškaraca i žena.

Dobijeni rezultati ukazuju da su se muškarci i žene sa akutnim moždanim udarom statistički značajno razlikovali u odnosu na uzrasti konzumiranje alkohola.

Ključne reči: akutni moždani udar, pol, zdravstvene navike, lična anamneza

\section{UvoD}

Akutni moždani udar (AMU) se definiše kao fokalni ili globalni poremećaj moždane funkcije, koji naglo nastaje, traje duže od 60 minuta, a posledica je poremećaja moždane cirkulacije ili stanja u kome protok krvi nije dovoljan za metaboličke potrebe neurona za kiseonikom i glukozom (1).

Moždani udar (MU) je jedan od vodećih uzroka morbiditeta u svetu. MU je takođe drugi najčešći uzrok de- mencije, najčešći uzrok epilepsije kod starijih i jako čest uzrok depresije (1).

Podaci o prevalenciji moždanog udara su verovatno najbolji pokazatelji o širenju ovog oboljenja u populaciji kao i pravljenju strategije zdravstvene zaštite u određenoj oblasti.

Prevalencija u svetu se kreće oko $5 \%$, a ta cifra varira u različitim područjima. Tako u Italiji ona iznosi 1,47 \%, UK $1,7 \%$, a u SAD 2,6 \%o (2). 
MU je treći uzrok smrti u razvijenim zemljama, posle kardiovaskularnih i malignih bolesti, a drugi uzrok smrti u celom svetu. Prema podacima Svetske Zdravstvene Organizacije, stopa mortaliteta od MU je 103 na 100.000 za muškarce, a 130 na 100.000 za žene, mada postoje varijacije (veća je u nerazvijenim državama) (3).

Smatra se da je oko 4,6 miliona smrtnih slučajeva uzrokovanih moždanim udarom godišnje, od toga je tri četvrtine ovih slučajeva u razvijenim zemljama (4).

Prema podacima o stopama mortaliteta uzrokovane moždanim udarom u Evropi, dokazne su značajne razlike između istočnih i zapadnih zemalja ovog kontinenta, $u$ istočnim mortalitet moždanog udara veći je nego u zapadnim zemljama (5).

U Evropi, najniža stopa mortaliteta od moždanog udara je u Švajcarskoj 27/100.000, a najviša u Bugarskoj 249/100.000 (2).

Internacionalna epidemiološka istraživanja pokazuju da javljanje moždanog udara eksponencijalno raste sa uzrastom (6). Što se Evropskog regiona tiče, procenat populacije osoba starijih od 65 godina, kod kojih se moždani udar najviše pojavljuje, porašće sa $20 \%$ u 2000. godini na 35\% u 2050. godini . Incidencije kod muškaraca najniža je u Francuskoj i Švajcarskoj, a najviša u Letoniji. Kod žena, najniža stopa incidenicije je u Francuskoj, Švajcarskoj i Slovačkoj, a najviša u Letoniji i Grčkoj (7). Prema registru južnog Londona, od MU češće obolevaju muškarci nego žene (8).

U Srbiji, moždani udar je vodeći uzrok smrti u ženskoj populaciji $(20,8 \%$ svih smrtnih ishoda) i drugi po učestalosti u muškaraca (15,5\%) (9).

$\mathrm{Na}$ osnovu rezultata studije sprovedene u Beogradu, sirova stopa incidencije iznosila je $288,7 / 100.000$, i to za muškarce 307,8/100.000 a za žene 270,6/100.000 (10). U Beogradu, prosečna standardizovana stopa mortaliteta za period 1989-2003. godine iznosila je 90,8 na 100.000 stanovnika, i to 98,0 na 100.000 za muškarce i 82,4 na 100.000 za žene, sa najvišim vrednostima u periodu 1994-1998. godine (11).

Osim što se radi o bolesti sa veoma visokim stepenom mortaliteta, podjednako je ozbiljna činjenica da je ovo neurološka bolest sa najvećim stepenom invaliditeta. Oko 4 miliona ljudi boluje od posledica moždanog udara. Od toga oko 570000 slučajeva potiče iz Evrope, a oko 500000 iz Sjedinjenih Američkih Država (2).

Faktori rizika za akutni ishemijski moždani udar (AIMU) su isti kao i za aterosklerozu, pa se zajedničkim imenom zovu vaskularni faktori rizika. Standardna podela je na one na koje se ne može uticati (uzrast, pol, rasa, etnička pripadnost, hereditet) i na faktore na koje se može uticati (arterijska hipertenzija, dijabetes melitus i poremećaji glikoregulacije u vidu hiperinsulinemije i insulin rezistencije, pušenje cigareta, zloupotreba alkohola, dislipidemija, kardiološki poremećaji, itd. ) (1).

Cilj rada je bio da se ispita da li postoje razlike po polu u potencijaljnim faktorima rizika za nastanak akutnog moždanog udara.

\section{Materijal i metode}

Studijom preseka, obuhvaćeni su pacijenti sa dijagnozom akutnog moždanog udara koji su hospitalizovani u period 1-31. novembra 2014. godine u Specijalnoj bolnici za cerebrovaskularna oboljenja Sveti Sava u Beogradu. Ukupan broj hospitalizovanih pacijenata sa dijagnozom akutnog moždanog udara u datom periodu bio je 113, od toga 57 muškaraca $(50,4 \%)$ i 56 žena $(49,6 \%)$.

Detaljnim pregledom otpusnih lista ovih pacijenata, prikupljeni su podaci o potencijalnim faktorima rizika, koji bi mogli uticati na nastanak AMU. Pored podataka o osnovnim demografskim karakteristikama pacijenata, kao što su pol, uzrast i mesto stanovanja, prikupljeni su i podaci o njihovim životnim navikama (pušenje cigareta, konzumiranje alkohola) i ličnoj anamnezi (arterijska hipertenzija, dijabetes melitus, dislipidemija, kardiološki poremećaji (aritmija, srčana dekompezacija, koronarna bolest), ateroskleroza).

U cilju ispitivanja razlika u pojedinim demografskim karakteristikama, zdravstvenim navikama i ličnoj anamnezi između muškaraca i žena sa akutnim moždanim udarom, u statističkoj obradi podataka korišćene su metode deskriptivne statistike, $\chi^{2}$ it test. Kompjuterska obrada podataka izvršena je primenom softverskog paketa "SPSS 20.0 for Windows".

\section{Rezultati}

U periodu 1-30. novembra 2014. godine, 113 pacijenata sa dijagnozom akutnog moždanog udara bilo je hospitalizovano u Specijalnoj bolnici za cerebrovaskularna oboljenja Sveti Sava u Beogradu. U toku istraživanja bio je hospitalizovan približno isti broj muškaraca (57/113; $50,4 \%)$ i žena (56/113; 49,6\%). Prosečna starost izražena u godinama ( \pm standardna devijacija) bila je $69,39(9,68)$ za muškarce i 74,52 $(11,4)$ za žene. Procenat pacijenata starijih od 65 godina iznosio je $71,9 \%$ za muškarce i $78,6 \%$ za žene. Većina obolelih pacijenata živela je u gradu (73,7\% muškaraca i 73,2\% žena).

Distribucija pacijenata sa akutnim moždanim udarom po polu, uzrastu i mestu stanovanja data je u Tabeli 1. 
Tabela 1. Distribucija pacijenata sa akutnim moždanim udarom po polu, uzrastu i mestu stanovanja

\begin{tabular}{|c|c|c|c|}
\hline \multirow[b]{2}{*}{ Karakteristike } & \multicolumn{2}{|c|}{ POL } & \multirow[t]{2}{*}{ Ukupno } \\
\hline & $\begin{array}{c}\text { Muškarci } \\
(\mathrm{n}=57)\end{array}$ & $\begin{array}{l}\text { Žene } \\
(\mathrm{n}=56)\end{array}$ & \\
\hline Uzrast (godine): $\mathrm{X} \pm \mathrm{SD}$ & $69,39 \pm 9,68$ & $74,52 \pm 11,4$ & $71,93 \pm 10,70$ \\
\hline $\begin{array}{l}\text { Uzrast (godine): broj (\%) } \\
\quad \leq 65 \\
\quad>65\end{array}$ & $\begin{array}{l}16(28,1) \\
41(71,9)\end{array}$ & $\begin{array}{l}112(21,4) \\
444(78,6)\end{array}$ & $\begin{array}{l}28(24,8) \\
85(75,2)\end{array}$ \\
\hline $\begin{array}{l}\text { Mesto stanovanja: broj (\%) } \\
\text { grad } \\
\text { selo }\end{array}$ & $\begin{array}{l}42(73,7) \\
15(26,3)\end{array}$ & $\begin{array}{l}441(73,2) \\
115(26,8)\end{array}$ & $\begin{array}{l}83(73,5) \\
30(26,5)\end{array}$ \\
\hline
\end{tabular}

Ta bela 2. Distribucija muškaraca i žena sa akutnim moždanim udarom prema sadašnjem pušačkom statusu i konzumiranju alkohola

\begin{tabular}{|c|c|c|c|}
\hline \multirow[t]{2}{*}{ Karakteristike } & \multicolumn{2}{|c|}{ POL } & \multirow[t]{2}{*}{$p$ vrednost } \\
\hline & $\begin{array}{c}\text { Muškarci }(\mathrm{n}=57) \\
\text { Broj }(\%)\end{array}$ & $\begin{array}{c}\text { Žene }(\mathrm{n}=56) \\
\text { Broj }(\%)\end{array}$ & \\
\hline $\begin{array}{l}\text { Sadašnji pušači: } \\
\mathrm{Da} \\
\mathrm{Ne}\end{array}$ & $\begin{array}{l}27(47,4) \\
30(52,6)\end{array}$ & $\begin{array}{l}21(37,5) \\
35(62,5)\end{array}$ & 0,289 \\
\hline $\begin{array}{l}\text { Konzumiranje alkohola: } \\
\mathrm{Da} \\
\mathrm{Ne}\end{array}$ & $\begin{array}{l}18(31,6) \\
39(68,4)\end{array}$ & $\begin{array}{c}6(10,7) \\
50(89,3)\end{array}$ & 0,007 \\
\hline
\end{tabular}

${ }^{*}$ Prema $\chi^{2}$ testu

Tabela 3. Druga oboljenja u ličnoj anamnezimuškaraca i žena sa akutnim moždanim udarom

\begin{tabular}{|c|c|c|c|}
\hline \multirow[b]{2}{*}{ Lična anamneza } & \multicolumn{2}{|c|}{ POL } & \multirow[t]{2}{*}{ p vrednost* } \\
\hline & $\begin{array}{c}\text { Muškarci (n=57) } \\
\text { Broj (\%) }\end{array}$ & $\begin{array}{c}\text { Žene }(\mathrm{n}=56) \\
\text { Broj }(\%)\end{array}$ & \\
\hline $\begin{array}{l}\text { Hipertenzija: } \\
\mathrm{Da} \\
\mathrm{Ne}\end{array}$ & $\begin{array}{c}55(96,5) \\
2(3,5)\end{array}$ & $\begin{array}{c}53(94,6) \\
3(5,4)\end{array}$ & 0,633 \\
\hline $\begin{array}{c}\text { Dijabetes: } \\
\mathrm{Da} \\
\mathrm{Ne}\end{array}$ & $\begin{array}{l}29(50,9) \\
28(49,1)\end{array}$ & $\begin{array}{l}23(41,1) \\
33(58,9)\end{array}$ & 0,296 \\
\hline $\begin{array}{l}\text { Ateroskleroza: } \\
\text { Da } \\
\mathrm{Ne}\end{array}$ & $\begin{array}{l}44(77,2) \\
13(22,8)\end{array}$ & $\begin{array}{l}43(76,8) \\
13(23,2)\end{array}$ & 0,959 \\
\hline $\begin{array}{l}\text { Dislipidemija: } \\
\mathrm{Da} \\
\mathrm{Ne}\end{array}$ & $\begin{array}{l}14(24,6) \\
43(75,4)\end{array}$ & $\begin{array}{l}17(30,4) \\
39(69,6)\end{array}$ & 0,490 \\
\hline
\end{tabular}

${ }^{*}$ Prema $\chi^{2}$ testu

Prema rezultatima $t$ testa, prosečna starost muškaraca $(69,39 \pm 9,68$ godina) je bila manja nego kod žena $(74,52 \pm 11,4)$ i ta razlika je bila statistički značajna $(t=2,62 ; D F=111 ; p=0,010)$. Međutim, nije bilo statistički značajne razlike po polu kada su posmatrane samo starije osobe (preko 65 godina) $\left(\chi^{2}=0,67 ; p=0,414\right)$ i prema mestu stanovanja $\left(\chi^{2}=0,01 ; \mathrm{p}=0,955\right)$.

U Tabeli 2 prikazana je distribucija muškaraca i žena prema pušačkom statusu i konzumiranju alkohola.

Iako je veći procenat pušača bio je među muškarcima $(47,4 \%)$ u odnosu na žene (37,5\%), ispitivane grupe nisu se značajno razlikovale $u$ odnosu na pušački status $\left(\chi^{2}=1,13 ; \mathrm{p}=0,289\right)$.
Muškarci su značajno češće, u odnosu na žene konzumirali alkohol i ta razlika je bila statistički značajna $\left(\chi^{2}=7,35 ; p=0,007\right)$.

Druga oboljenja u ličnoj anamnezi muškaraca i žena sa akutnim moždanim udarom prikazana su u Tabeli 3.

Muškarci i žene nisu se razlikovali u odnosu na prisustvo drugih bolesti u ličnoj anamnezi kao što su hipertenzija $\left(\chi^{2}=0,23 ; p=0,633\right)$, dijabetes $\left(\chi^{2}=1,09 ; p=0,296\right)$, ateroskleroza $\left(\chi^{2}=0,01 ; \mathrm{p}=0,959\right)$ i dislipidemija $\left(\chi^{2}=0,47\right.$; $\mathrm{p}=0,490)$.

U tabeli 4 prikazani su kardiološki poremećaji muškaraca i žena sa akutnim moždanim udarom. 
Tabela 4. Kardiovaskularni poremećaji muškaraca i žena sa akutnim moždanim udarom

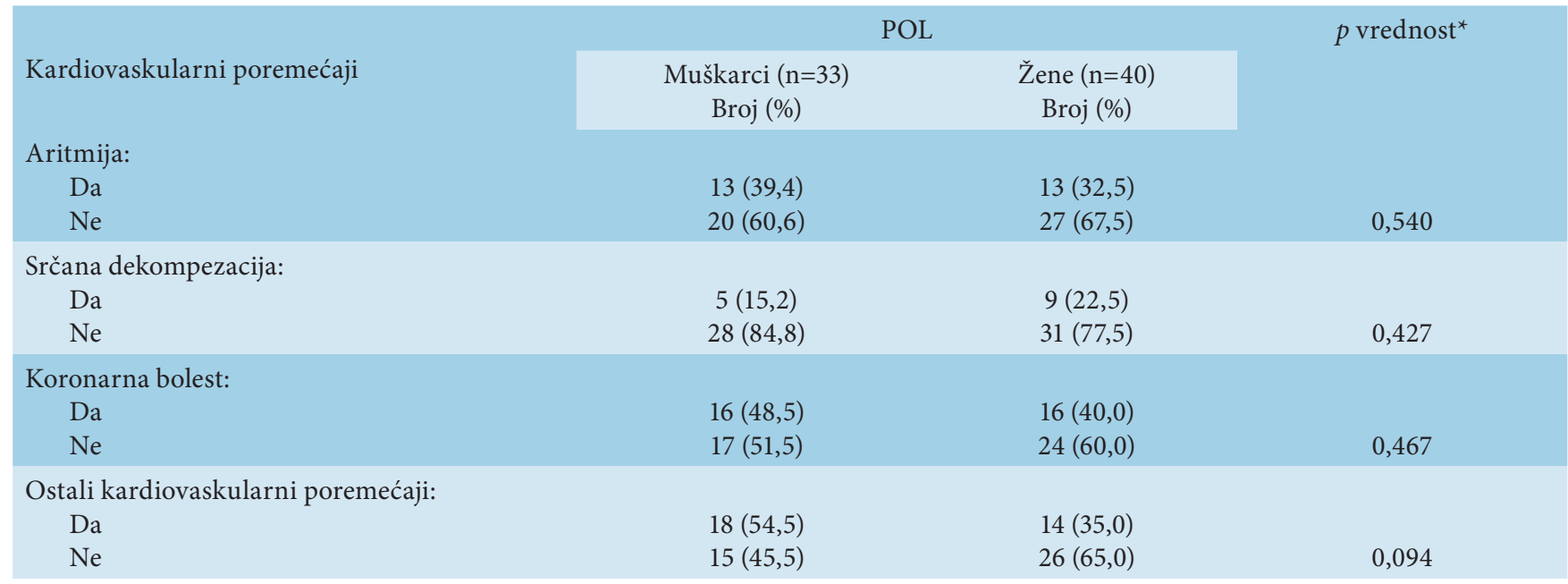

${ }^{\star}$ Prema $\chi^{2}$ testu

Rezultati našeg istraživanja pokazuju, da su žene (40/56; $71,4 \%)$ češće imale neki od kardiovaskularnih poremećaja u ličnoj anamnezi nego muškarci (33/57; 57,9\%), ali nije postojala statistički značajna razlika među ispitivanim grupama $\left(\chi^{2}=2,26 ; p=0,133\right)$. Muškarci su češće $(13 / 33 ; 39,4 \%)$ u odnosu na žene $(9 / 40 ; 22,5 \%)$ imali više od jednog kardiovaskularnog poremećaja ali i ta razlika nije bila statistički značajna $\left(\chi^{2}=2,45 ; \mathrm{p}=0,117\right)$. Takođe, nije bilo statistički značajne razlike između muškaraca i žena u odnosu na prisustvo pojedinih kardiovaskularnih bolesti kao što su aritmija $\left(\chi^{2}=0,38 ; p=0,540\right)$, srčana dekompezacija $\left(\chi^{2}=0,73 ; p=0,427\right)$, koronarna bolest $\left(\chi^{2}=0,37 ; p=0,467\right)$ i ostale kardiovaskularne bolesti $\left(\chi^{2}=2,41 ; \mathrm{p}=0,094\right)$.

\section{DISKUSIJA}

U studiji u kojoj je učestvovalo 113 pacijenata hospitalizovanih u specijalnoj bolnici Sveti Sava u Beogradu, bio je približno isti broj pacijenata muškog i ženskog pola. Žene su u proseku bile starije od muškaraca, što se slaže sa podacima u literaturi (12).

Rosamond i saradnici naglašavaju da je učestalost moždanog udara kod muškaraca veća sa godinama, ali da žene starije od 85 godina imaju veću učestalost obolenja (13). Smatra se da je manja učestalost kod žena u mlađem životnom dobu zbog polnih hormona koji učestvuju u prevenciji oboljenja pre svega estrogena (14). Goldstein i saradnici označavaju čitav niz faktora rizika kao što su šećerna bolest, hipertenzija, pušenje, gojaznost i drugi kao veoma značajne u nastank akuttnog moždanog udara (15).

Pojedina srčana oboljenja se u literturi pominju kao nezavisni faktor rizika za nastanak akutnog moždanog udara (16).

U velikoj kohortnoj studiji u Italiji, autori pronalaze vezu između nivoa obrazovanja i faktora rizika za obo- ljenje, naglašavajući da preventivne aktivnosti treba da bude usmerene na osobe sa nižim socioekonomskim statusom (17).

Veronesi i saradnici pokazuju da muškarci i žene sa nižim socioekonomsklim statusom imaju 2 puta veću šansu za dobijanje akutnog moždanog udara (18). Ova veza se objašnjava nedovoljnim prihvatanjem značaja kako terapije za oboljenje tako i nedovoljnim shvatanjem prevencije faktora rizika (19).

Jedan od pokazatelja socioekonomskog stanja je i mesto stanovanja. U našoj studiji nije uočena značajna razlika po polu u odnosu na mesto stanovanja.

Veza između konzumiranja alkohola i moždanog udara je proučavana u mnogim studijama. Reynolds i saradnici navode da je prekomerno konzumiranje alkohola povezano sa moždanim udarom (20), dok pojedine studije naglašavaju da umereno konzumiranje alkohola može biti čak i protektivni efekat za moždani udar (21).

U ovoj studiji muškarci su značajno češće konzumirali alkohol, što se delimično može objasniti i kulturološkim navikama u populaciji.

\section{OgRANiČENJE STUdiJE}

Ova studija je imala i određena ograničenja. Kao prvo, to je bio dizajn studije, koja kao studija preseka ima svoje mane, zatim mali broj ispitanika, a i relativno mali broj faktora rizika koji su se ispitivali.

\section{ZAKLJUČAK}

Prosečan uzrast pacijenata sa moždanim udarom bio je veći kod žena nego kod muškaraca. Muškarci su značajno češće konzumirali alkohol u odnosu na žene, dok u 
ostalim ispitivanim faktorima rizika za nastanak akutnog moždanog udara nije bilo statistički značajnih razlika između muškaraca i žena.

Detaljnija istraživanja potencijalnih faktora rizika za nastanak akutnog moždanog udara putem drugih stu- dija i to na većem broju ispitanika, svakako bi mogla da ukažu na faktore rizika za nastanak ovog poremećaja zdravlja. Ovo je važno u cilju promena životnih navika koje dovode do nastanka ove bolesti, tj. primenom adekvatnih primarnih i sekundarnih mera prevencije za akutni moždani udar.

\section{Literatura}

1. The European Stroke Organisation (ESO) Executive Committee and The ESO Writing Committee. Guidelines for management of ischaemic stroke and transient ischaemic attack. Cerebrovasc Dis 2008; 25 . 457-507.

2. Zhang Y, Champan A M, Plested M, Jakson D, Purroy F The incidence, and mortality of stroke in France, Germany, Italy, Spain, the UK and US: A literature Review. Hindawi Publishing Corporation. Stroke Research and Treatment 2012

3. Tanaka H, Iso H, Yokoyama T, et al. Cerebrovascular disease. Oxford Textbook of Public Health, 4th ed. Oxford: Oxford University Press; 2002 .

4. Thorn T J 1993 Stroke mortality trends: an international perspective. Ann Epidemiol 3:509-518).

5. Sarti C, Rastenyte D, Cepaitis Z, Tuomilehto J. Internationaltrends in mortality from stroke, 1968 to 1994.Stroke 2000; 31: 1588-1601

6. Dragutin K, Marinko D, Milan B, et al. Prevalence of acute cerebrovascular disease in Bizovac, Osijek-Baranya county: a door-to-door survey in eastern Croatia , Pub Med 2007; 61(3):315-8

7. T. Truelsen, B. Piechowski-Jo'z'wiak, R. Bonita, et al, Stroke incidence and prevalence in Europe: a review of available data, European Journal of Neurology 2006, 13: 581-598

8. Wolfe CD, Rudd AG, Howard R, et al. Incidence and case fatality rates of stroke subtypes in a multiethnic population: the South London Stroke Register. Journal of Neurology, Neurosurgery and Psychiatry 2002; 72: 211-216.

9. Atanacković Marković Z, Bjegović V, Janković S, et al. The Burden of Disease and Injury in Serbia. Ministry of Health of Republic of Serbia, Belgrade, 2003.

10. Pekmezović T, Beslac-Bumbaširevic Lj, Djoković S. et al. Incidence of stroke in the population of Belgrade (Serbia): preliminary results. Cerebrovasc Dis 2010;29(Suppl.2):252

11. Pekmezović T, Tepavčević DK, Jarebinski M, et al. Stroke mortality in Belgrade, Serbia: age, period, and cohort analyses. Cerebrovasc Dis 2007;24(2-3):191-5

12. Yesilot NF, Koyuncu BA, Coban O, Tuncay R, Bahar SZ. Gender differences in acute stroke: Istanbul medical school stroke registry. Neurol India. 2011 Mar-Apr;59(2):174-9.
13. Rosamond W, Flegal K, Friday G, et al. Heart disease and stroke statistics - 2007 update: a report from the American Heart Association Statistics Committee and Stroke Statistics Subcommittee. Circulation. 2007;115:e69-e171

14. Cola MS, Gava AL, Meyrelles SS, Vasquez EC. Endothelial dysfunction of resistance vessels in female apolipoprotein E-deficient mice. Lipids Health Dis. 2010; 9:51. Pelligrino DA, Santizo R, Baughman VL, Wang Q. Cerebral vasodilating capacity during forebrain ischemia: effects of chronic estrogen depletion and repletion and the role of neuronal nitric oxide synthase. Neuroreport1998; 9: 3285-3291.

15. Goldstein LB, Adams R, Alberts MJ, et al. Primary prevention of ischemic stroke: a guideline from the American Heart Association/ American Stroke Association Stroke Council: cosponsored by the Atherosclerotic Peripheral Vascular Disease Interdisciplinary Working Group; Cardiovascular Nursing Council; Clinical Cardiology Council; Nutrition, Physical Activity, and Metabolism Council; and the Quality of Care and Outcomes Research Interdisciplinary Working Group: the American Academy of Neurology affirms the value of this guideline. Stroke 2006; 37: 1583-1633.

16. Wolf PA, Abbott RD, Kannel WB. Atrial fibrillation as an independent risk factor for stroke: the Framingham Study. Stroke. 1991;22:983-988.

17. Fornari C, Donfrancesco C, Riva MA, et al. Social status and cardiovascular disease: a Mediterranean case. Results from the Italian Progetto CUORE cohort study. BMC Public Health. 2010; 24:10:574.

18. Veronesi G, Ferrario MM, Chambless LE, et al. Gender differences in the association between education and the incidence of cardiovascular events in Northern Italy. Eur J Public Health. 2011; 21(6):762-7.

19. Panagiotakos DB, Pitsavos CE, Chrysohoou CA, et al. The association between educational status and risk factors related to cardiovascular disease in healthy individuals: The ATTICA study. Ann Epidemiol. 2004; 14(3):188-94

20. Reynolds K, Lewis LB, Nolen JD, Kinney LG. Alcohol consumption and risk of stroke: a meta-analysis. JAMA. 2003; 289: 579-588.

21. Sacco RL, Elkind M, Boden-Albada B. The protective effect of moderate alcohol consumption on ischemic stroke. JAMA. 1999; 281: 53-60. 